\title{
PERFORMANCE ANALYSIS OF REGIONAL GOVERNMENT OWNED ENTERPRISES BANK PERKREDITAN RAKYAT MAJATAMA AND THE REGIONAL WATER SUPPLY COMPANY OF THE MOJOKERTO REGENCY GOVERNMENT IN FINANCIAL PERSPECTIVE
}

\author{
Kariyoto \\ Brawijaya University
}

\begin{abstract}
Purpose - The purpose of this study is to evaluate the performance of the Mojokerto Regency 2019 Regional Owned Enterprises (BUMD).

Design/methodology/approach - The research method used is descriptive qualitative analysis. The stages of preparatory research determine the techniques used in the analysis. The next stage gathers indicators in measuring financial performance. Determine the criteria in accordance with the theory used for financial performance analysis. Collection and analysis of financial data of BPR Majatama and the Regional Water Company.

Findings - The results of the study show that Majatama People's Credit Bank Study of the Gross Value of Bad Debt in July, August, September, and October 2019 are safe.

Originality/value - This study evaluates the performance of the People's Credit Bank Majatama. It also evaluates the performance of the Regional Water Supply Company and provides performance recommendations.

Practical Implication - The calculation of Gross and Net non-performing loans experiences a positive trend and is far from the maximum limit required by Bank Indonesia of 5\%. Regional Water Supply Companies in July, August, September, and October 2019, management is advised to control the general administrative costs, increase revenue and reduce operating costs through efficiency and effectiveness to increase profits in the following month.
\end{abstract}

Research Type Research Paper

Keywords Performance, Regional-Owned Enterprises, Majatama Rural Credit Banks, and Regional Water Companies. 


\section{INTRODUCTION}

The law of the Republic of Indonesia number 23 of 2014 concerning regional government states that the implementation of regional government is directed to accelerate the realization of community welfare through improving services, empowerment, and community participation, and increasing regional competitiveness with pay attention to the principles of democracy, equality, justice and the uniqueness of an area in the system of the Unitary State of the Republic of Indonesia. Autonomy is the right, authority, and obligation of the autonomous region to regulate and manage their own government affairs and the interests of the local community in the system of the Unitary Republic of Indonesia. In this connection, the sources of regional revenue in the context of implementing autonomy and decentralization including Original Regional Revenues; Balance Funds; Regional Loans; and other legal receipts. Sources of local own-source revenues are included but not limited to local taxes, regional levies, results of regional-owned companies, and other regionallyseparated regional assets. In connection with this, regional businesses sourced from Regionally Owned Enterprises have been running for quite a long time. Regionally Owned Enterprises are formed based on Law No. 5 of 1962 concerning regional companies was later strengthened by Law No. 5 of 1974 concerning the principles of Regional Government. Regionally-owned Business Entities are formed to carry out the development of each region through providing services to the community, organizing public benefits, and increasing local government income.

Regionally Owned Enterprises are divided into group caves, that is, regional companies serving the public interest and regional companies to increase regional revenue in the region's original income. Regionallyowned Enterprises are engaged in various business fields, namely financial and banking services, clean water services, and various other products services and businesses in the industry, agriculture, plantations, trade and hospitality, parking, printing, and others.

Research activities on Regionally Owned Enterprises are generally intended to encourage regional governments in the context of increasing the implementation of regional autonomy activities so that they can

implement good governance. The purpose of research on regionallyowned enterprises, in particular, is to increase the ability in good 
company management and to support the company's goals in improving the ability to provide services to customers and to obtain optimal profits. Based on the publication of the Central Statistics Agency in the Mojokerto Regency in Figures as for the Gross Regional Income of the Mojokerto Regency based on the Price Applicable within the last 3 years are

Table 1. Gross Regional Regional Income of Mojokerto Regency Based on Applicable Prices

\begin{tabular}{cc}
\hline Year & Amount \\
\hline 2016 & Rp 65.115.825,40 \\
2017 & Rp 70.863.170,44 \\
2018 & Rp 76.768.633,45 \\
\hline
\end{tabular}

Whereas the Gross Regional Regional Income figure based on constant prices in the last 3 years are :

Table 2. Gross Regional Income of Mojokerto Regency At constant prices

\begin{tabular}{rc}
\hline Year & Amount \\
\hline 2016 & $\operatorname{Rp~49.360.593,70~}$ \\
2017 & $\operatorname{Rp~52.192.821,03~}$ \\
2018 & $\mathrm{Rp} \mathrm{55.248.488,09}$ \\
\hline
\end{tabular}

\section{RESEARCH METHOD}

This research method is intended to provide an overview of the stages used in performance analysis of the condition of the Rural Bank of Majatama and the Regional Water Supply Company of Mojokerto Regency by using a descriptive qualitative analysis method of financial data of Mojokerto Regency-Owned Regional Enterprises.

\subsection{Research Stages}

a. Stages of preparation namely formulating the objectives carried out the analysis.

b. Define aspects to be analyzed. 
c. Select and determine the techniques that will be used in the analysis.

d. Arrange measurement tools that are used as indicators in measurement and financial performance. Determine benchmarks or criteria according to the theory used for financial performance analysis.

e. Processing of results from collecting data on performance and financial reports of the Bank Perkreditan Rakyat Majatama and the Regional Water Supply Company of Mojokerto Regency.

f. Report from an analysis of the financial performance of the Majatama Rural Bank and Regional Water Supply Company of Mojokerto Regency.

Based on the stages of the implementation of the research that has been compiled, a framework is made into two groups, based on the object being evaluated, namely the Perkreditan Rakyat Majatama Bank and the Regional Drinking Water Company of Mojokerto Regency. The Framework for Thinking is adapted to the objectives of performance evaluation and financial statements.

\subsection{Framework for Thinking}

\section{a. PT Bank Perkreditan Rakyat Majatama}

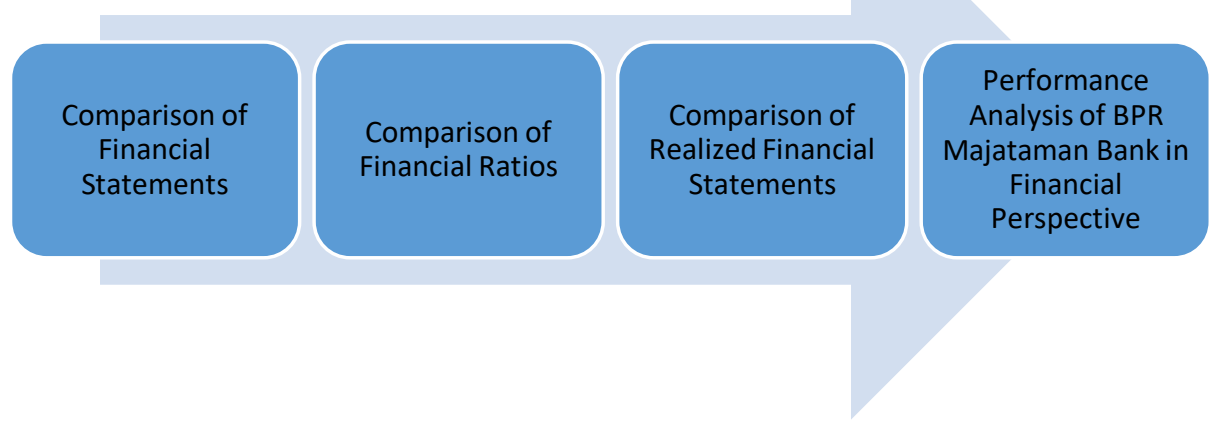

The method used is as follows: 
1. Financial report data collection and determination of performance indicators used in the evaluation process of PT BPR Majatama Mojokerto

2. Comparing the Realized Financial Statements Per Month owned by PT BPR MAJATAMA Mojokerto.

3. Calculate monthly BPR health ratios such as Capital Adequacy (CAR), Return on Assets (ROA), NPL, LDR, and Cash Ratio.

4. Comparing the Realized Financial Statements and Budget per month.

5. Compilation of evaluation report and performance recommendation at PT BPR Matamaja Mojokerto

\section{b. Regional Water Supply Company of Mojokerto Regency}

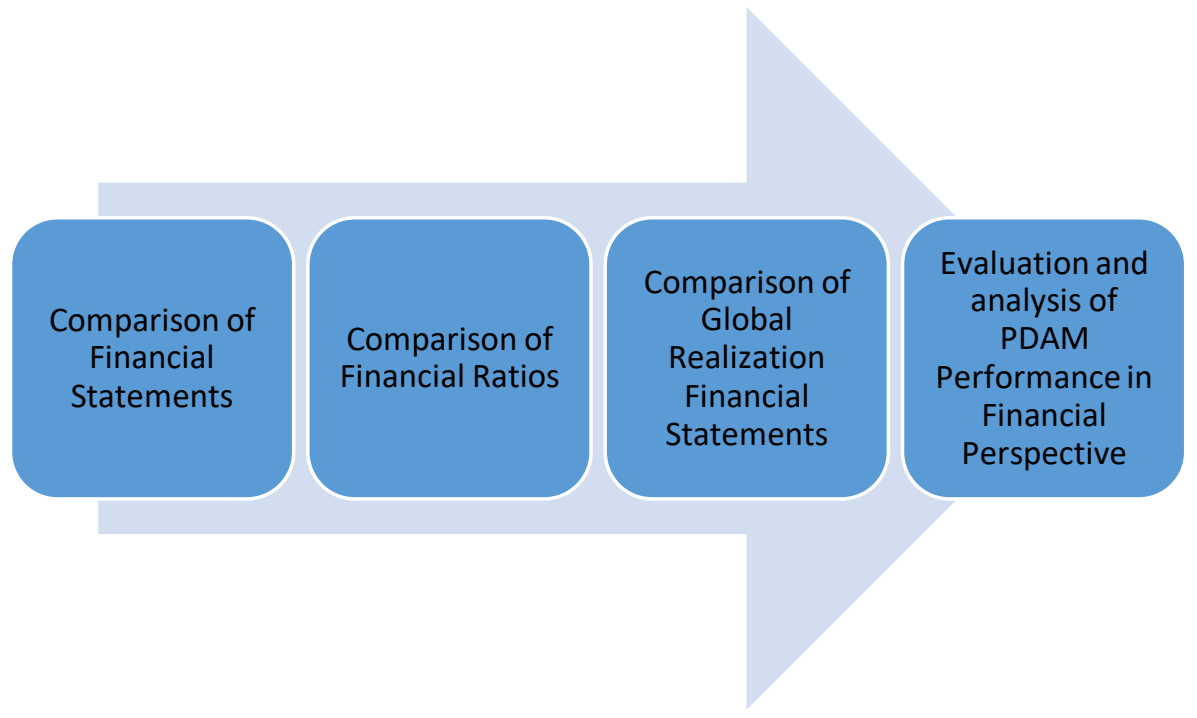

The method used is as follows:

1. Collecting financial statement data and determining performance indicators used in the evaluation process of the Mojokerto Regency Water Supply Company (PDAM)

2. Comparing the Realized Financial Statements and the 2019 budget of the Regional Water Supply

Company of Mojokerto Regency.

Vol. 28, No. 3 December 2020

(C) Centre for Indonesian Accounting and Management Research Postgraduate Program, Brawijaya University 
3. Take into account financial ratios such as ROE, Ratios Operations, Cash Ratios, Billing Effectiveness, and Solvency Ratios;

4. Take into account service ratios such as service coverage, customer growth, level of complaint resolution, customer water quality and domestic water consumption;

5. Take into account operating ratios such as production efficiency, water loss rate, service operating hours, customer connection pressure, and water meter replacement;

6. Calculate Human Resources ratios such as the ratio of the number of employees, the ratio of employee training, and training costs to employee expenses.

7. Give a Conclusion.

\section{RESULTS AND DISCUSSION}

\subsection{Profile Bank Perkreditan Rayat Majatama}

Bank Perkreditan Rakyat Majatama is a Regionally-Owned Business Entity engaged in Banking. The Majatama Rural Credit Bank has been operating since 1979 under the name Regional Bank Market Company, based on the Regional Regulation of the Second Level Regional District of Mojokerto Number 5 of 1979. Later in 1994, the name of the Regional Bank Regional Market Company was renamed as the Rural Bank Regional Market Level II Mojokerto Regency Based on Mojokerto Level II Regional Regulation Number 10 of 1994 concerning Regional Banks Rural Banks Regional Banks.

The purpose and objective of helping and encouraging economic growth and regional development in all fields and as one source of regional income in order to improve the standard of living of the people with the following efforts:

a. Collecting funds from the public in the form of time deposits and savings, and/or other forms offered with it.

b. Give financial credits to small businesses and/or rural communities as well as civil and private employees.

c. Conducting other banking businesses as long as they do not conflict with the applicable laws and regulations.

\section{b. Company Profile Perusahaan Daerah Air Minur Mojokerto}

Vol. 28, No. 3 December 2020

(C) Centre for Indonesian Accounting and Management Research

Postgraduate Program, Brawijaya University 
The Regional Water Supply Company is one of the regional-owned business units engaged in the distribution of clean water to the general public in every province, district, and municipality throughout Indonesia. Regional companies as a means of providing clean water are monitored and monitored by the regional executive and legislative apparatus.

Modern state-run water companies have existed since the Dutch colonial era. In 1962 Law No. 5 on Regional Enterprises and the PDAM has started to form until now. By its very nature, companies must perform two types of functions. First is to run an economic function, which is looking for profit and the second one is to carry out social functions related to the purpose of article 33 of the 1945 Constitution, namely managing

businesses that control the lives of many people, especially the provision of clean and healthy water facilities for the community.

Regional Water Supply Company located in Mojokerto Regency, Pahlawan street no. 4 Mojokerto, East Java. It has a total of 82 employees and 12,117 active customers. The population of the service area is 280,000 and the administration population is 1,000,049.

Financial Analysis Results

\section{PT. Bank Perkreditan Rakyat Majatama}

\section{a. Business Conditions}

PT. Bank Perkreditan Rakyat Majatama.

Business volume during semester II 2019 tends to decrease. The position of the financial statements as of August 31, 2019, compared to July 2019, explained that the business volume of PT. Bank Perkreditan Rakyat has increased. The percentage increase of $2.43 \%$ or $\mathrm{Rp} 1,890,388$ thousand from Rp. 77,637,984.ribu to Rp. 79,528,372. The increase in income was due to an increase in several accounts, in the asset account, namely cash at $40.75 \%$, placements at other banks $4.16 \%$, loans granted $1.25 \%$, fixed assets investing $0.89 \%$. On the liability side, there were also increases including immediate liabilities of $24.48 \%$, savings deposits of $7.01 \%$, deposit deposits of $0.73 \%$, and other liabilities of $6.06 \%$. 
However, on the other hand, there were some decreases including interest income to be received $13.72 \%$, other assets $5.50 \%$, and interest debt $0.75 \%$. The position of the financial statements as of 31 October 2019 compared to September 2019 explained that the business volume of PT. The Majatama People's Credit Bank has increased. The percentage increase of $0.22 \%$ or $\mathrm{Rp} 143,891$ thousand from Rp. 66,113,511 thousand to Rp. 66,257,402 thousand. The increase was due to several accounts experiencing an increase, among others, interest income to be received $15.05 \%$, loans granted $4.67 \%$, immediate liabilities $13.28 \%$, interest loans $3.38 \%$, savings deposits of $3.50 \%$ and liabilities another $5.19 \%$.

Table 3. Business Volume of PT. BPR Bank Majatama (000)

\begin{tabular}{lcccc}
\hline Information & July & August & September & October \\
\hline Business & 77.637 .984 & 79.528 .372 & & \\
Volume & & & 66.113 .511 & 66.257 .402 \\
\hline
\end{tabular}

\section{a. Development of $\mathrm{R} / \mathrm{L}$}

Table 4. Profit of PT. The People's Credit Bank Majatama in the second semester of 2019 experienced fluctuating conditions (000)

\begin{tabular}{lcccc}
\hline Infomation & July & August & September & October \\
\hline & 1.241 .947 & 79.528 .372 & & \\
Profit & & & 1.688 .571 & 1.874 .095 \\
\hline
\end{tabular}

\section{Development of $\mathbf{R} / \mathrm{L}$}

PT. Perkreditan Rakyat Majatama in the second semester of 2019 is relatively stable. BPR Majatama's profit on August 31, 2019, increased compared to the previous month's position. An increase in profit of Rp. 148,554 thousand or $11.96 \%$. The increase in overall profit was due to an increase in operating income by $14.51 \%$. Placements with other banks' current accounts with $0.65 \%$, Placements with other banks with savings at $31.53 \%$, Placements with other banks with deposits of $14.96 \%$, loans granted to non-bank third parties by $14.44 \%$, provision of loans to nonbank third parties by $15.14 \%$. BPR Majatama's profit on 31 October 2019 increased compared to the previous month's position. An increase in profit 
of Rp. 185,524 thousand or $10.99 \%$. The increase in overall profit was due to an increase in operating income by $11.97 \%$. Placements with other banks' current accounts with $0.70 \%$, Placements with other banks with savings of $15.82 \%$, Placements with other banks with deposits of $7.00 \%$, loans granted to non-bank third parties at $12.97 \%$, provision of loans to non-bank third parties by $11.39 \%$.

\section{a. Capital Ratio}

Calculation of capital adequacy ratio of PT. Bank Majatama Rural Credit is obtained by determining the value of the Capital Adequacy Ratio (CAR). CAR is obtained from comparing capital with risk-weighted assets multiplied by one hundred percent.

Table 4. The results of the calculation of CAR PT Bank Perkreditan Rakyat Majatama in the second semester of 2019

\begin{tabular}{lcccc}
\hline Information & & Agust & September & October \\
& July & & & \\
\hline CAR & $40,85 \%$ & $39,74 \%$ & $41,42 \%$ & $39,83 \%$ \\
\hline
\end{tabular}

Based on the calculation results in the table above, it is explained that the capital adequacy ratio of PT. Bank Perkreditan Rakyat Majatama experienced a change that was not too significant in the second semester of 2019. The change did not affect the capital position of PT. Majatama Rural Credit Bank is in a healthy position. PT. Bank Perkreditan Rakyat Majatama can be concluded is still able to close if there is a decline in assets due to bank losses caused by risky assets.

\section{a. Earning Asset Ratio}

Calculation of the ratio of earning assets of PT. Rural Bank of Majatama Bank is obtained by determining the amount of Gross and Net NonPerforming Loans (NPL). Gross NPL value is obtained by comparing non-performing loans to total loans. Meanwhile, the net NPL is obtained by comparing the value of problem loans minus Allowance for Impairment Losses to total loans.

Based on the gross and net NPL table above, it states that the risk of PT. Bank Perkreditan Rakyat Majatama experienced problem loans in 
the healthy/good category. Based on the calculation of Gross and Net NPLs in the second semester of 2019. Based on the calculation of Gross NPLs in August decreased by $0.22 \%$ while the Net NPL decreased by $0.23 \%$. And the calculation of Gross NPL in October decreased by $0.10 \%$ while the Net NPL decreased by $0.17 \%$, so the percentage of non-performing loans was below $5 \%$.

The strategies to reduce the risk of non-performing loans that are still high include increasing collections on overdue loans, adding credit facilities, extending credit terms, and reducing loan principal arrears.

From the steps above, the increase in the credit debit or expansion tray is prioritized. By expanding, there is a positive domino effect, namely the achievement of annual work plans in terms of the amount of credit extended. As a result, loan interest income also has the potential to increase.

This step needs to get support from company elements, namely by maximizing the Human Resources function of credit marketing by increasing the amount or increasing capacity. In addition, it is necessary to create and implement an incentive policy towards staff related to the credit performance

\section{c. Profitability Ratio}

Calculation of PT. Bank Perkreditan Rakyat Majatama is obtained by determining the value of Return on Assets (ROA), Return on Equity (ROE), and Operating Expense (BOPO) ratio. ROA is obtained by comparing earnings before tax to total assets while ROE is obtained by comparing earnings after tax to total equity. The BOPO ratio is obtained by comparing the value of operating expenses with the value of operating income. 
Table 6. The results of the calculation of ROA, ROE, and BOPO of PT. BPR Majatama in the Second Semester of 2019

\begin{tabular}{lrccc}
\hline Information & July & August & $\begin{array}{c}\text { Septembe } \\
\mathrm{r}\end{array}$ & October \\
\hline ROA & $3,18 \%$ & $3,14 \%$ & $3,45 \%$ & $3,56 \%$ \\
ROE & $19,10 \%$ & $18,86 \%$ & $19,24 \%$ & $19,52 \%$ \\
BOPO & $79,95 \%$ & $80,12 \%$ & $78,72 \%$ & $78,53 \%$ \\
\hline
\end{tabular}

ROA PT. BPR Majatama in July and August explained that there was a decrease of $0.04 \%$. This percentage suggests that the ability of bank assets to generate profits in August 2019 has decreased. In the ROE ratio described above occurs a value that decreases by $0.24 \%$. Calculation of this ratio explains that the ability of capital owned to generate profits in August 2019 has decreased compared to the previous month. BOPO Ratio, calculation results of BOPO Ratio of PT. BPR Majatama showed an increase of $0.17 \%$ compared to July 2019. The meaning of the increase was an increase in the efficiency process of operational expenses and an increase in efforts to increase operating income.

ROA calculation above, explains that an increase of $0.11 \%$. This percentage suggests that the ability of bank assets to generate profits in October 2019 has increased. In the ROE ratio described above a score of $0.28 \%$ occurred. The calculation of the ratio explains that the ability of capital owned to generate profits in October 2019 has increased compared to the previous month. BOPO Ratio, calculation results BOPO Ratio shows a decrease of $0.19 \%$ compared to September 2019. The meaning of the decline is a decrease in the process of operational load efficiency and a decrease in efforts to increase operating income even though the decrease ratio is not significant.

\section{d. Liquidity Ratio}

The calculation of the liquidity ratio of PT. People's Credit Bank Majatama is obtained by determining the value of the Current Ratio 
(CR) and Loan to Deposit Ratio (LDR). The Current Ratio is used to measure the company's ability to pay off short-term obligations. Loan to Deposit Ratio (LDR) is obtained by comparing total loans with funds from third parties.

Table 7. The results of the calculation of CR and LDR of PT. BPR Majatama in the second semester of 2019

\begin{tabular}{lrccc}
\hline \multicolumn{1}{c}{ Information } & July & August & September & October \\
\hline CR & $8,78 \%$ & $36,15 \%$ & $14,96 \%$ & $4,77 \%$ \\
LDR & $63,98 \%$ & $63,34 \%$ & $78,78 \%$ & $62,82 \%$ \\
\hline
\end{tabular}

In August 2019 there was a significant increase in the Current Ratio of $27.37 \%$ compared to July 2019. The calculation results explained that the position of PT. BPR Majatama to pay its short-term debt in August 2019 increased. However, the LDR percentage in August 2019 decreased by $0.64 \%$.

In October 2019 there was a significant decrease in the Current Ratio of $10.19 \%$ compared to October 2019. The calculation results explained that the position of PT. BPR Majatama to pay its short-term debt in October 2019 decreased. The percentage of LDR in October 2019 decreased by $15.96 \%$.

\section{PDAM of Mojokerto Regency \\ a. Business Conditions}

Table 8. The Development of Mojokerto Regional Water Supply Company Business Volume in the second semester of 2019 is relatively stagnant, illustrated from the following table:

\begin{tabular}{ccccc}
\hline Information & July & August & September & October \\
\hline Volume Usaha & 38.295 .115$. & 39.082 .963$. & 39.712 .106 .2 & 42.522 .231 .0 \\
& 428 & 695 & 28 & 66 \\
\hline
\end{tabular}


Business volume in July 2019 with August 2019, the business volume of the Mojokerto Regional Water Supply Company increased by Rp. $787,848,266.79$ or $2.06 \%$. The increase was obtained from changes in the value of assets valued at Rp. 38,295,115,428,52. To Rp. 39,082,963,695,31. The increase was due to an increase in several accounts including cash $8.30 \%$, water receivables $8.04 \%$, allowance for receivables $9.29 \%$, Office Stationery inventory $10.07 \%$ printing inventory $5.62 \%$, installation materials $11.87 \%$, Advances for Income Tax 25, 20.36\%, Trade debts 3399.49\%, other debts 10.88\%, Debt Tax $2525.88 \%$, deposits $0.87 \%$ and Value Added Tax 0.62\%. Although on the other hand there was a decrease in the Bamguman Tax Receivable account by $26.20 \%$. Business volume in October 2019 with September 2019, business volume increased by $\mathrm{Rp}$. $2,810,124,838$ or $7,076 \%$. The increase was obtained from changes in the value of assets valued at $\mathrm{Rp}$. 39,712,106,228.71 to $\mathrm{Rp}$. $42,522,231,066.62$. The increase was due to an increase in several accounts including cash and cash equivalents of $175.80 \%$, Office Stationery Supplies 772.60\%, Advances for PPh 2525 691.10\%, Trade Payables $1.34 \%$, deposits and $152.52 \%$.

\section{b. Calculation of Performance Value of Financial Aspects}

Table 9. Calculation of Performance Value of Financial Aspects of Mojokerto Regional Water Supply Company

\begin{tabular}{|c|c|c|c|c|}
\hline Indicator & July & August & $\begin{array}{l}\text { Septem } \\
\text { ber }\end{array}$ & $\begin{array}{c}\text { Octobe } \\
\mathrm{r}\end{array}$ \\
\hline Profitability & & & & \\
\hline $\begin{array}{l}\text { a. Renturn on } \\
\text { Equity }\end{array}$ & 0,11 & 0,11 & 0,11 & 0,11 \\
\hline b. Operating & 0,16 & 0,165 & 0,165 & 0,165 \\
\hline Ratio & 5 & & & \\
\hline $\begin{array}{l}\text { Liquidity } \\
\text { a. Cash Ratio }\end{array}$ & $\begin{array}{l}0,27 \\
5\end{array}$ & 0,275 & 0,275 & 0,275 \\
\hline
\end{tabular}

Vol. 28, No. 3 December 2020

(C) Centre for Indonesian Accounting and Management Research Postgraduate Program, Brawijaya University 


\begin{tabular}{lllll}
\hline \multicolumn{1}{c}{ Indicator } & July & August & $\begin{array}{c}\text { Septem } \\
\text { ber }\end{array}$ & $\begin{array}{c}\text { Octobe } \\
\text { r }\end{array}$ \\
\hline b. Billing & 0,27 & 0,22 & 0,275 & 0,275 \\
Effectiveness & 5 & & & \\
Solvency & 0,15 & 0,15 & 0,15 & 0,15 \\
\hline $\begin{array}{c}\text { Total Weight } \\
\text { of Financial }\end{array}$ & $\mathbf{0 , 9 7}$ & $\mathbf{0 , 9 2}$ & $\mathbf{0 , 9 7 5}$ & $\mathbf{0 , 9 7 5}$ \\
Performance & & & & \\
\hline
\end{tabular}

Profitability aims to measure the company's ability to generate profits for a certain period and measure the level of effectiveness of management in carrying out the company's operations. The profitability of local water companies is measured using two indicators, namely Return on Equity and Operating Ratio.

Calculation of Return On Equity by dividing net income from total equity. The July $2019 \mathrm{RoE}$ value shows a positive number with a value of 2 . The value shows the company's ability to generate profits using equity in July 2019 is not yet fully maximized. Regional Water Company is expected to maximize equity optimally due to the resulting profit of 0.012 of total equity. The August $2019 \mathrm{RoE}$ value shows a positive number with a value of 2 . The value shows the company's ability to generate profits using equity in August 2019 has not been fully maximized. Regional Drinking Water Companies are expected to maximize equity optimally due to the resulting profit of 0.014 of total equity. The September $2019 \mathrm{RoE}$ value shows a positive number with value 2 . This value shows that the company's ability to generate profits using the equity in September 2019 has not been fully maximized and optimally maximizes equity due to the resulting profit of 0.11 of total equity. The October RoE value shows a positive number with a value of 2 . The value shows the company's ability to generate profits using equity in October 2019 is not fully maximized. Besides this, it is expected to maximize equity optimally due to the resulting profit of 0.11 of total equity.

Operating Ratio is calculated by dividing Operating Expenses against Operating Revenues. Operating Ratios are concluded with a value of less than 3. Based on the measurement results show 
management is less able to perform efficiently and control operating expenses. In addition, management is expected to make more efforts to increase revenue so that the revenue value is higher to cover operating expenses. Value of income of Rp. 2,502,379,945.00 while the Operating expenses are Rp. 1,917,864,129.33 Based on the cost structure, it is known that administrative and general costs reach a ratio of $42.49 \%$ of the total operational costs. This percentage shows that administrative and general costs contributed significantly to the total operating costs in October 2019. For the month

Furthermore, management is advised to control general administrative expenses. Liquidity is an indicator to assess a company's ability to meet its obligations. Liquidity is measured using two indicators namely Cash Ratio and Billing Effectiveness.

The cash ratio is calculated by dividing the amount of cash and cash equivalents by the number of current liabilities. Based on the results of the calculation of the cash ratio can be concluded very well with a value of 5 or conditions $>100 \%$. This value explains that the amount of cash and cash equivalents in October 2019 is very high and able to meet/pay off the short-term debt that is due. The cash ratio assessment for October 2019 needs to be maintained and improved by continuing to carry out the company's cash flow control.

Billing Effectiveness is an indicator to show the ability to effectively manage sales results (Water Receivables) so that it becomes revenue. The effectiveness of billing is measured by dividing the number of water bill receipts by the number of water bills. Based on the measurement results, billing activities undertaken by management can be concluded either with a standard value of 5 or a condition of $101.65 \%$. This achievement explains that the process of improving services related to quality, quantity, and continuity has been in full accordance with public expectations.

Solvency aims to determine the ability of assets to guarantee the long-term debt. Therefore, the calculation is to divide the number of assets by the number of liabilities. The calculation results show that the value of solvency in October 2019 amounted to> 200\% or with a 
standard value of 5. This value explains that the value of assets is very high and total long-term debt is low. It was concluded that assets can guarantee the long-term debt. The assessment of the solvency ratio in October 2019 is maintained and enhanced by continuing to carry out debt repayment payments according to the agreed schedule.

\section{b. Calculation of Service Aspect Performance Value}

Table 10. Table of Calculation of Performance Value of Service Aspects of PDAM Mojokerto

\begin{tabular}{lcccc}
\hline \multicolumn{1}{c}{ Indicator } & July & August & $\begin{array}{c}\text { Septemb } \\
\text { er }\end{array}$ & October \\
\hline $\begin{array}{l}\text { Service Coverage } \\
\text { Technical }\end{array}$ & 0,05 & 0,05 & 0,05 & 0,05 \\
$\begin{array}{l}\text { Customer Growth } \\
(\% / \text { Year })\end{array}$ & 0,05 & 0,05 & 0,05 & 0,05 \\
$\begin{array}{l}\text { Complaint } \\
\begin{array}{l}\text { Settlement Rate } \\
\text { Customer Water }\end{array}\end{array}$ & 0,125 & 0,125 & 0,125 & 0,125 \\
$\begin{array}{l}\text { Quality } \\
\text { Domestic Water } \\
\text { Consumption }\end{array}$ & 0,05 & 0,375 & 0,375 & 0,375 \\
\hline $\begin{array}{l}\text { Total Service } \\
\text { Performance } \\
\text { Weight }\end{array}$ & $\mathbf{0 , 6 5}$ & $\mathbf{0 , 6 5}$ & 0,05 & 0,05 \\
\hline
\end{tabular}

Scope of Technical Services. This indicator aims to determine the ability of Management in providing water services to its technical area. The formula for calculating the scope of technical services is to divide the number of people served compared to the total population of service areas. The calculation results show that the value of Technical Services Coverage is 1 with conditions/standards of only $2.28 \%$. The assessment gives the meaning that service coverage is still low because $<20 \%$. One potential problem that can be identified is because the community's interest in subscribing is still low due to alternative water sources that are still widely available. So it is 
necessary to have a new connection fee discount program for new customers at a certain place and time.

Customer Growth. Customer growth illustrates the activity in trying to increase the number of customers. The formula for calculating customer growth indicators is to divide the number of customers in this period minus the number of customers last period by the number of customers last period. The calculation results show that customer growth by $0.00 \%$ with a standard value of 1 . This percentage explains that customer growth in July, August, September, and October 2019 is categorized as very low. need to improve the distribution service network so that it can continue to increase customer growth.

Level of Complaints. This indicator illustrates the level of management activity in an effort to resolve water service complaints or other complaints. The formula used is to divide the number of customer complaints handled by the number of complaints. Based on the measurement results, the level of complaint resolution is very satisfying. Measurement figures indicate a standard value of 5 or 100\%. In July, August, September, October 2019 the number of complaints was $23,23,26,29$ complaints and all complaints were handled properly and thoroughly. The performance aspect of the complaint resolution indicator that needs to be maintained is that the customer complaint service system has been well planned so that all complaints can be resolved according to customer expectations.

Customer Water Quality. This indicator illustrates the ability to serve customers with the quality of drinking water service $(3 \mathrm{~K})$ in accordance with Permenkes No. 492 / Menkes / PER / V / 2010 concerning drinking water quality requirements. The formula used is to divide the number of tests that meet the requirements compared to the amount tested. Based on the test results, the water quality of customers in July, August, September, and October 2019 was concluded to have met the permissible limits based on Permenkes RI No. 416/ Menkes/Per/IX/1990 concern-ing water quality requirements. The total number of tests is 16 areas and all tests meet the requirements or $100 \%$ 
Domestic Water Consumption. This measurement aims to determine the average level of water consumption per household customer in one month in the year concerned. The formula used to measure these indicators is to divide the average amount of water sold to domestic customers by the number of domestic customers. Calculation results show that domestic water consumption for July, August, September, and October 2019 amounted to $17.25 \%, 16.68 \%$, $16.87 \%, 17.28 \%$ with a standard value of 1 . The interpretation of the results of these measurements is water consumption domestic investment is still very low. One potential problem that can be identified is that alternative water sources are still widely available. So there is a need for a program to add a distribution pipeline system.

\section{d. Calculation of Performance Value of Operational Aspects}

Table 11. Calculation of Operational Aspects Performance Values

\begin{tabular}{|c|c|c|c|c|}
\hline Indicator & July & August & $\begin{array}{c}\text { Septembe } \\
\mathbf{r}\end{array}$ & October \\
\hline $\begin{array}{l}\text { Production } \\
\text { Efficiency }\end{array}$ & 0,35 & 0,35 & 0,35 & 0,35 \\
\hline Water Loss Rate & 0,35 & 0,35 & 0,35 & 0,35 \\
\hline $\begin{array}{l}\text { Service Operating } \\
\text { Hours }\end{array}$ & 0,40 & 0,40 & 0,40 & 0,40 \\
\hline $\begin{array}{l}\text { Water Pressure on } \\
\text { Customer } \\
\text { Connections }\end{array}$ & 0,325 & 0,325 & 0,325 & 0,325 \\
\hline Replacement & 0,065 & 0,065 & 0,065 & 0,065 \\
\hline $\begin{array}{c}\text { Total Operating } \\
\text { Performance } \\
\text { Weight }\end{array}$ & 1,49 & 1,49 & 1,49 & 1,49 \\
\hline
\end{tabular}

1. Production Efficiency

The indicator shows the level of efficiency in utilizing its paired capacity. Production efficiency is measured by dividing production realization by installed capacity. Based on the calculation results, the Production Efficiency Value is 5 with a standard $>90 \%$. This explains that the level of production 
efficiency is very high. This positive achievement was due to the successful development of the distribution network that had been developed.

2. Non-billed water

Indicator to measure management's ability to control the volume of water sold through the pipeline distribution system. The indicator is calculated by dividing the distribution of water minus water sold by water distribution. The results of measurements in July 2019 showed that the rate of water loss reached a percentage of $25.66 \%$ with a value of 5 . The results revealed that there were indications that as much as $25.66 \%$ of water was wasted because there were some improper pipe connections so there needed to be an improvement on the pipe. In addition, there is a need for regular supervision of the water distribution network to customers. The level of water loss in July 2019 is categorized as very low. The results of measurements in August 2019 showed that the level of water loss reached a percentage of $15.16 \%$ with a value of 5 . The results revealed that there were indications as much as $15.16 \%$ of water was wasted because there were some improper pipe connections so there needed to be an improvement on the pipe. In addition, there is a need for regular supervision of the water distribution network to customers. The level of water loss in August 2019 is categorized as very low. The results of measurements in September 2019 showed that the level of water loss reached a percentage of $14.66 \%$ with a value of 5 . The results revealed that there were indications that as much as $14.66 \%$ of water was wasted because there were some improper pipe connections so there needed to be an improvement on the pipe. In addition, there is a need for regular supervision of the water distribution network to customers. The level of water loss in

September 2019 is categorized as very low. The results of measurements in October 2019 showed that the rate of water loss reached a percentage of $16.92 \%$ with a value of 5 . The results revealed that there were indications that as much as $16.92 \%$ of water was wasted because there were some improper pipe connections so there needed to be an improvement on the pipe. In

Vol. 28, No. 3 December 2020

(C) Centre for Indonesian Accounting and Management Research Postgraduate Program, Brawijaya University 
addition, there is a need for regular supervision of the water distribution network to customers. The level of water loss in October 2019 is categorized as very low.

\section{Service Operation Hours}

The indicator is used to determine the ability to provide drinking water services to its customers 24 hours a day continuously. The calculation formula is to divide the time of water distribution to customers by the evaluation period. Based on the measurement results, the service operating hours are carried out 21.6 hours per day with a standard value of 5 . The achievement explains that the service operating hours are already very high and does not limit the distribution operating hours so that water usage by customers is not limited by time.

\section{Water Pressure on Customer Connections}

This indicator is used to determine the achievement of water pressure on the average customer pipe. The formula for calculating the water pressure indicator on customer connections is by dividing the number of customers served by the pressure of 0.7 bar by the number of customers in October 2019. Based on the measurement results, the ratio of water pressure at customer connections is $100 \%$ with a standard value of 5 . The achievement explains that the pressure 0.7 bar of water in the Mojokerto area is evenly distributed. These positive results need to be maintained by continuing to check the water pressure on the customer's connection.

\section{Customer Water Meter Replacement}

Indicators used to assess management's ability to replace water meters. The formula used to assess the indicator is to divide the number of water meters of customers replaced by the number of customers. Based on the results of the calculation, the ratio of customer water meter replacement is $0 \%$ with standard value 1 . The results explain there is a possibility that the customer water meter condition inspection program is not yet available. Need to budget funds for the procurement and replacement of customer water meters. 


\subsection{Calculation of Performance Value Aspects of Human Resources}

Table 12. Calculation of Performance Value Aspects of Human

Resources

\begin{tabular}{|c|c|c|c|c|}
\hline Indicator & July & August & $\begin{array}{c}\text { Septembe } \\
\mathbf{r}\end{array}$ & October \\
\hline $\begin{array}{l}\text { Employee to } \\
\text { Customer Ratio }\end{array}$ & 0,35 & 0,35 & 0,35 & 0,35 \\
\hline $\begin{array}{l}\text { Employee training } \\
\text { ratio (Competency } \\
\text { Enhancement) }\end{array}$ & 0,04 & 0,04 & 0,04 & 0,04 \\
\hline Training Cost Ratio & 0,04 & 0,04 & 0,08 & 0,04 \\
\hline $\begin{array}{l}\text { Total HR } \\
\text { Performance }\end{array}$ & 0,43 & $\mathbf{0 , 4 3}$ & 0,47 & $\mathbf{0 , 4 3}$ \\
\hline
\end{tabular}

1. The ratio of Number of Employees

This indicator is used to measure employee efficiency towards customers. To measure the ratio of the number of employees is to divide the number of employees by the number of customers divided by one thousand. The calculation results show that the standard value of the ratio of the number of employees is 5 or $<6$ people. This explains that the ratio of employees to customers is in the efficient category. The number of employees is in ideal condition and can cover the number of customers in the city of Mojokerto.

2. Education and training ratio

Vol. 28, No. 3 December 2020

(C) Centre for Indonesian Accounting and Management Research Postgraduate Program, Brawijaya University 
This indicator is used to assess employee competency levels. The formula is used by dividing the number of employees who take part in the training and the number of employees. The measurement results revealed that the employee education and training ratio of $1.65 \%$, $0.00 \%, 2.40 \%, 1.60 \%$. The ratio states that the education and training ratio for July, August, September, and October is very low. Efforts should be made to send and increase the number of employees participating in the training. In addition, it can search for information on training facilities to be held and submit training proposals to the central government such as the Water Sanitation Engineering Center, BPPSPAM, Ditpam.

3. The burden of Education and Training Against Employee Burden This indicator is to determine the ability of management to appreciate trying to make employees competent. The formula used is to divide the amount of training load by the number of employee expenses. The calculation results explain that the ratio of training expenses to employee expenses is $2.45 \%, 0.00 \%, 4.49 \%, 2.61 \%$. The results of these calculations explain that there is an allocation of education and training costs in July, August, September, and October 2019 in the low category. This explains that the Regional Water Supply Company has an appreciation in trying to make its employees competent. Hopefully, it will continue to seek information on training facilities to be held and submit training proposals to the central government such as the Water Sanitation Engineering Center, BPPSPAM, Ditpam.

\section{CONCLUSION}

\subsection{PT. BPR Majatama}

1. Gross Non-Performing Loan Value in July, August, September, and October 2019 in the Safe category. Calculation of Non-Performing Loans Gross and Net experienced a positive trend and away from the maximum limit required by Bank Indonesia of 5\%. The NonPerforming Loan Net and Gross Calculation Position still needs to be considered by management to be maintained and improved and resolve problem loans. 
2. Steps to reduce the risk of higher non-performing loans include increasing collections on overdue loans, adding credit facilities, extending credit terms, and reducing the principal arrears.

3. Bank Perkreditan Rakyat Majatama can prioritize increased expansion. By expanding, there will be a positive domino effect for increasing the achievement of annual work plans in terms of the amount of credit given. As a result, loan interest income also has the potential to increase.

\subsection{Regional Water Supply Company}

Performance values based on the analysis results in July, August, September, and October 2019 as outlined above then the proposed strategy.

1. Management is advised to control general administrative expenses;

2. Submitting training proposals to the central government such as the Agency for the Development of Drinking Water Supply System (BPPSAM), DitPAM in addition to entering the Education and Training Service Travel Order (SPPD) in the Education and Training costs.

3. Increasing revenue and reducing operating expenses through efficiency and effectiveness of expenses will have a significant impact on improving the performance of the return on equity indicator. So, it can increase profits in the following month. 


\section{REFERENCES}

Implementing Agency for the Development of Drinking Water Supply Systems (BPPSPAM). 2007. Technical Guidance on Performance Evaluation of PDAMs. Jakarta: BPPSPAM

Jumingan. 2006. Analysis of Financial Statements. Jakarta: Earth Literacy. PU Permen Number 18 Year 2007. About the Organizing Agency for the Development of Drinking Water Supply Systems (BPPSPAM) Law Number 3 of 1998. Regarding Legal Entity Business Entities. Law Number 23 Year 2014. About Regional Government

Law Number 40 Year 2007. About Limited Liability Companies and Regulations for its implementation 
Vol. 28, No. 3 December 2020 (C) Centre for Indonesian Accounting and Management Research Postgraduate Program, Brawijaya University 